樹脂加工糸および布の動的モジュラスの測定につレて

$\begin{array}{lllll}\text { 群馬大学工学部 } & \text { 下 } & \text { 茂 武 } \\ \text { 山形大学工学部 行 方 寅 次 郎 }\end{array}$

\title{
ON MEASUREMENT OF DYNAMIC MODULUS OF VISCOSE SPUN RAYON YARN AND FABRIC TREATED WITH UREA-FORMALDEHYDE RESIN
}

\author{
By Shigetake Kinoshita* and Torajiro Namikata*** \\ (* Faculty of Engineering, Gumma University, Kiryu, Japan) \\ (** Faculty of Engineering. Yamagata University, Yonezawa Japan)
}

The dynamic Young's modulus and damping capacity of each of 14 samples of same viscose spun rayon yarns and fabrics treated with several contents of urea-formaldehyde resin were measured by the vibrating reed method in vacuum at room temprature, and obtained the following results:

1) In the observation of the influence of the resin content on the dynamic Young's modulus of yarn and fabric treated with resin, it was found that the dynamic Young's modulus was increased as the resin content was increased and that the values of dynamic Young's modulus of every treated yarn was higher than the values of corresponding fabrics. (see Fig.4)

2) By measuring the influence of the resin content on the damping capacity of yarn and fabric treated with urea-formaldehyde resin, it was found that the variation of the values of damping capacity with various resin contents on yarn or fabric was not distinct, although the values of the damping capacity of every treated fabric were higher than thoes of corresponding yarns. (see Fig. 5)

(Received April 22, 1958)

\section{緒論侖}

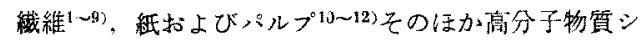
一ト13-13)に関する動付モジュラスの研究は数多く発表 されているが，䡴物関しては，乙の静的モジュラスの 測定法 ${ }^{21 \sim 24)}$ に比べて，動的そジュラス湘定法りの報告は 少ない。これは䋐維, 紙などのよ5な単一物体に地べて, 織物は㵶維および落の集合体かららな整造物であるが故 に，測定值の意味ずけが困難であることが理由と考えら れる。しかるに緎維篮品が実際使用される場合は，静的 状態に㧍けるよりも，むしろ動的状態に执ける場合が多 く、こラした点から考えてみても, 動的研究がより必要 になつて来るものと考充られる。かれわれは，そ5した 意味をらくめると同時化，また奉際上の必要から樹脂加 工糸抢よび鐵物の動的モジュラスを湖定し，そのオーダ

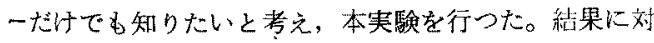
する詳細なる討論は後日に譲り，今回はこれまで行つた 奏験結果のみを述心゙，今後ますます盛んになるであらう と考えられる動的モジュラスの测定の糸口としたい。
Table. I Characteristics of Samples

\begin{tabular}{|c|c|c|c|c|}
\hline \multirow{2}{*}{$\begin{array}{c}\text { Sample } \\
\text { No. }\end{array}$} & \multirow{2}{*}{$\begin{array}{c}\text { Resin } \\
\text { content } \\
\%\end{array}$} & \multicolumn{2}{|c|}{$\begin{array}{l}\text { Apparent density } \\
\mathrm{g} / \mathrm{cm}^{\mathrm{g}}\end{array}$} & \multirow{2}{*}{ Remarks } \\
\hline & & Yarn & Fabric & \\
\hline 100 & 1.7 & 0.611 & 0.677 & \multirow{7}{*}{$\begin{array}{c}\text { Treated } \\
\text { with } 10 \% \\
\text { resin } \\
\text { Solution }\end{array}$} \\
\hline 110 & 3.8 & 0.628 & 0.688 & \\
\hline 120 & 4.5 & 0.633 & 0.696 & \\
\hline 130 & 5.1 & 0.654 & 0.699 & \\
\hline 140 & 5.8 & 0.672 & 0.703 & \\
\hline 150 & 6.2 & 0.686 & 0.710 & \\
\hline 160 & 13.5 & 0.710 & 0.725 & \\
\hline 200 & 6.5 & 0.663 & 0.699 & \multirow{3}{*}{$\begin{array}{l}\text { Treated } \\
\text { with } 15 \% \\
\text { resin } \\
\text { solution }\end{array}$} \\
\hline 210 & 8.8 & 0.682 & 0.701 & \\
\hline 220 & 10.8 & 0.694 & 0.705 & \\
\hline 300 & 2.4 & 0.632 & 0.684 & \multirow{4}{*}{$\begin{array}{c}\text { Treated } \\
\text { with } 20 \% \\
\text { resin } \\
\text { solution }\end{array}$} \\
\hline 310 & 5.7 & 0.648 & 0.693 & \\
\hline 320 & 6.6 & 0.669 & 0.693 & \\
\hline 330 & 7.6 & 0.680 & 0.699 & \\
\hline
\end{tabular}




\section{1. 試料および実駼方法}

供試試料として，糸はピスコース・スフ系 $40 / 2$ 's, 織 物は経䋨系ともビスコース・スフ系 $40 / 2^{\prime 8}$ 它用い,山形

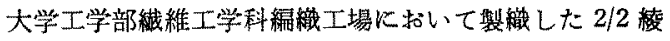

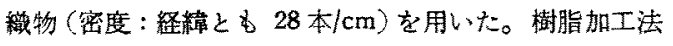
は承素ホルマリン樹脂加工法 $\left.{ }^{18}\right)$ そよつて, 同科䋐維加工 実験室に扰いて行つた。すなわち，尿素・ホルマリンの モル比 1:1.75なる未穛合佶脂を用い，触媒にはピコり ン㧍よびモノクロル酸酸を用いた。予桷乾燥は $75^{\circ} \mathrm{C} の$ 空気中括いて 10 分間, ベーキングは $125^{\circ} \mathrm{C}$ の空気中 そ和いて 15 分間加熱を行い, 数日間放置した後, 炭酸 ソーダ液を用いてソーピングを行つた。供試試料の種類 老 Table. I K示す。

実験装䈯ならびに方法は振動りード法1ー17)により, 同

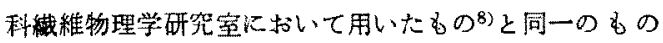
を用いて，真空度は 1〜10-1 $\mathrm{mmHg}$ であつた。な和测 定温度は室温とした。

実鵌に用いた試料の大きさについては，系の場合は， それぞれ掁動長を $0.8 ， 1.0 ， 1.2,1.4 \mathrm{~cm}$, 敉物の場合 は幅を $0.7 \mathrm{~cm}$, 振動長 $0.8,1.0,1.2,1.4 \mathrm{~cm} 0_{4}$
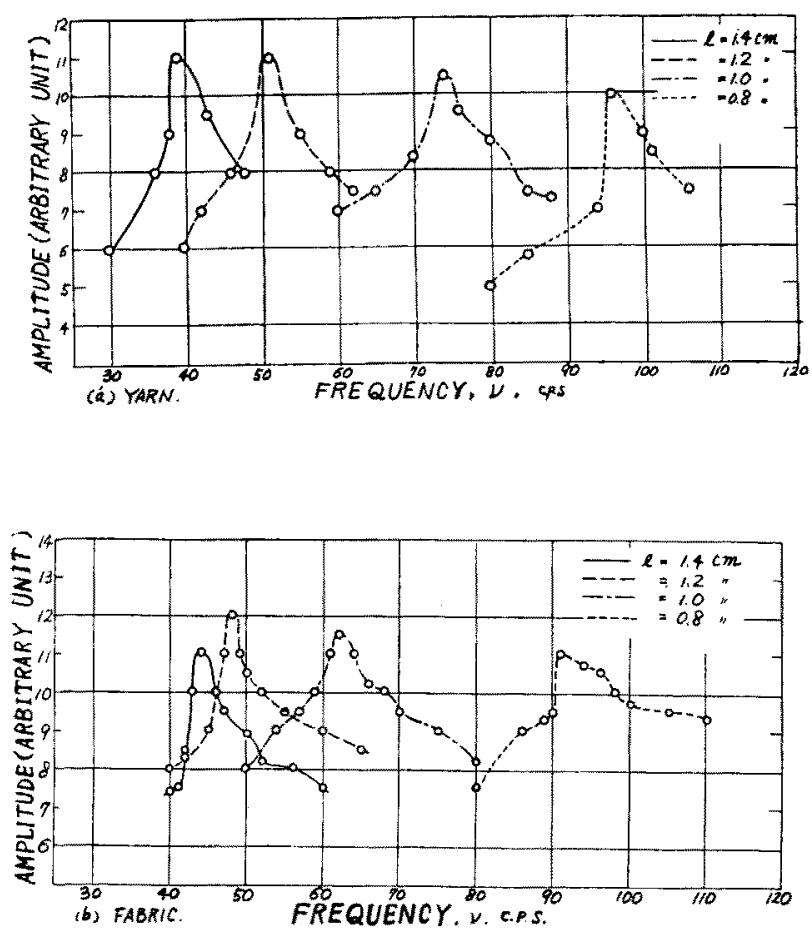

Fig. 1 Amplitude-frequency curves for viscose spun rayon yarn and fabric No. 101 at four different vibrating lengths $l$.

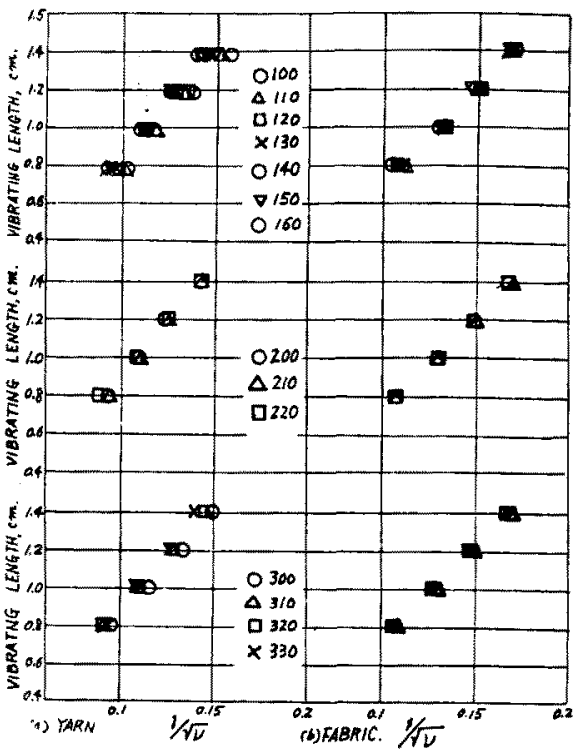

Fig. 2 Vibrating length vs. $1 / \sqrt{v}$ curves for viscose spun rayon yarn and fabric treated with resin.

種とした。測定は Table. I.に示した14 種

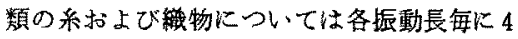
回安つ行つた。な枋，織物の場合恃経系の方 向汇とつて測定を行つた。

\section{2. 測 定 結 果}

振動リード法の測定理論に関しては前記の 諸諭文 述へれれば，電磁的に振動する鉄片の先端沉伡 料をつけ，歌動周波数を变元て辰幅を測定し， 共振曲線を作る。次比々の共症曲線の共振振 動数 $\nu$ と振幅が最大睢の $1 / \sqrt{2}$ になる点の 幅 $A v よ り$, 弹性係数 $E$ は次式によつて求 わられる

$$
E=\frac{\pi^{2} \rho A}{a_{0}^{4} I} l^{4} v^{2}\left[1+\frac{1}{8}\left(\frac{\Delta v}{v}\right)^{2}\right] \cdots
$$

こに $\rho$ は密度, $A$ は断面積， $l$ は振動 長，Iは断面の慣性能率， $a_{0}$ は层動型仗よ口 て定をる定数である。

基音（基本振動）飞対して $a_{0}=1.875$ と し，更に系扣上び織物の場合を考光测定に用 いた形に畫きかえると次式のよ了になる。

$$
\begin{aligned}
& E=51.1 \frac{\rho}{D^{2}} l^{4} \nu^{2} \\
& E=38.3 \frac{\rho}{h^{2}} l^{4} \nu^{2}
\end{aligned}
$$



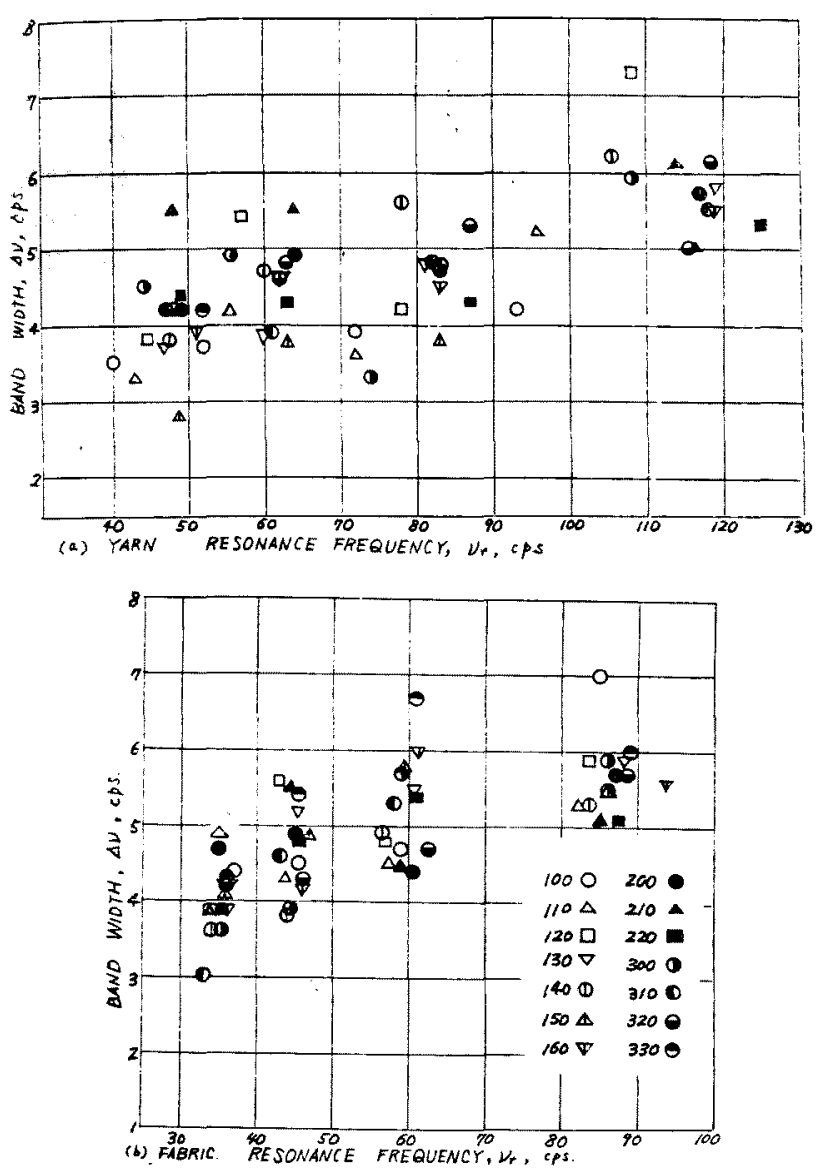

Fig. 3 Relation between band width and resonance frequency in viscose spun rayon yarn and fabric treated with resin.

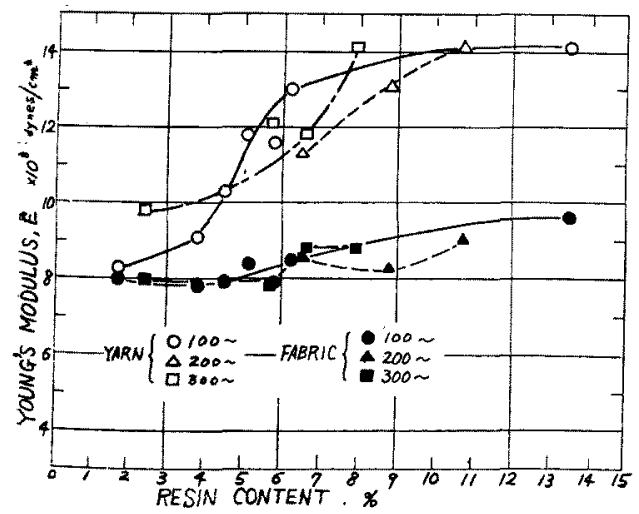

Fig. 4 Effect of resin content on Young's modulus in viscose spun rayon yarn and fabric treated with resin. る。 さなかつた。
(2)式は糸の場合に用い，Dは系の直 径，(3)式は暂物の場合に用い， $h$ は織 物の厚さを示す。な拉（1）式の第 2 項 は1対し極めて小さいので省略した。

また試料のダンピング・キャがシテー ぬは次式を用いて求めた成。

$$
\psi=1-e^{-2 \delta}
$$

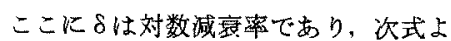
り求めた。

$$
\delta=\pi \Delta v / v
$$

測定結果を Fig.1〜Fig. 5 に示す。

Fig.1 は 14 種類の杀および織物の中 からNo.101 の夈拈よび織物をとり出 し，その振幅一振動数曲楾を示したもの である。図に示すように，共振振動数は 振動長を增すにしたがつて小さくなつて いる。な扰振幅は测定の関係上, 任意単 位をるつて表わした。

Fig. 2 は振動長 $l$ と $1 / \sqrt{v}$ との関係 を，稆軸に振動長，横軸に $1 / V v$ をと つて示したすのである。罒に示すように，

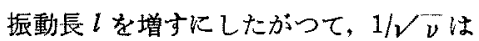
增加を示した。よつて，この結果に(2) (3)式を用小て試料の弹性倸数 $E$ の值 が求められる。

Fig. 3 は $1 / V 2$ 值軦 $\Delta v$ 之共振振動 数 $v_{r}$ との関倸を, 縦軸に $\Delta v$, 横軸に v。をとて示したすのである。Fig.3 (a) K示す上5に，系の場合は共振振動 数が変化しても $1 / \sqrt{2}$ 值幅がほとんど 変化しない傾句を示しているが，Fig.3 (b)に示すょうに，秘物の場合は共振振動が大きくる にしたがつて，1/V2 值輻も增大寸る傾向を示してい

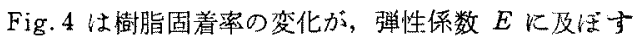
影艟を，縱軸に弹性係数 $E$, 横軸澍脂固着率をとつて 示したるのである。图に示すように, 杀执よび織物とる に, 樹脂固着蜜が増加するにしたがつて, 弾性係数が增 加の傾向を示した。

Fig. 5 は樹脂固着率の变化が，ダンピング・キャタシ

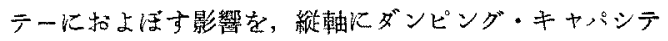
一 ，横軸に樹脂固着率をとつて示したものである。図 に示すよ5に糸执よび織物ともに，ダンピング・キャパ シデーは, 樹脂固着禀が変化しても, 汪とえど变化を示 


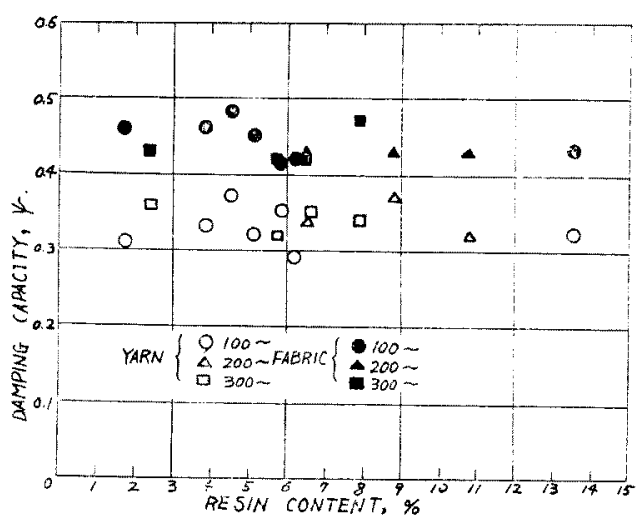

Fig. 5 Effect of resin content on damping capacity in viscose spun rayon yarn and fabric treated with resin.

\section{3. 討論}

\section{(1) 空気抵抗の影桃}

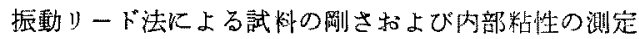
法に㧍いては，空気抵抗の影響が問題となる。たとえば E. M. Kärholm, B.Schröder 雨氏4仗 A. Oberbeck な らびに G.G.Stokes 両氏の式を用いて測定傎から空気 抵抗の影喑を除去することを試みている。われわれの実 験は空気王 1〜10-1 mmHg. 程度の真空中に和いて行わ れ，大気中に扣いて行われた测定と比較した場合，真空 中の方の共振点が，掁動数の高い方にずれたこと，また 消費係数 $Q^{-1}\left(=\Delta v / v_{r}\right)$ の值が真空中のbのの方が勂気 中のbのの方より隇少していることなどから，空気抵抗 の影響がほとんど㗝いすのと見てさしつかえなかつた。 ただしこの点に関する定量的な吟味は充分とは言えず， 断定は图難であるが，扣拓む水，前節の湘定值は試料固 有の弾㤬係数扣よびダンピング・キャパシテーみの值 であると言5ことがでさよ5。しかし，測定が真空中に 岁いて行われたため、これらの值は，乾燥状態における 佔であることに注意しなければならない。

\section{（2）単䋐稚, 䒺および緎物の弾性保数の比較}

糸の動的朋げ弹性倸数括上び織物の静的おょび動的曲 げ弾性係数を Table. II に㲾す。織物の静的曲げ弹性係 数の測定には，いわゆるカンチレバー武21, ${ }^{24}$ を用い，各 10 回行い，その平均值を湘定值とした。また単瀻維に ついては，樹脂加工を行つたため生じたクリンプなどに よつて動的測定ができなかつたので，その切断荷重の $60 \%$ 荷重にて伸長してから除重し, 履整曲楾を求め, その第2 履歴曲線から弹性绿数を計算し, その結果を Table，III(a) K示した。更に単緎維の動的測定に関し ては E.M.Kärholm, B. Schröder 両氏肪よび小野木
重治, 安藤昭三両氏方の論文の湘定值を引用し，これを Table. III(b)に示した。な报単絾維の静的特よび動的 弾性係数の比較に関しては前記の4 氏のほかＷ.J.Lyo$n^{19)}$, J.C.Guthrie, D.H.Morton, P.H. Oliver ${ }^{6)} の$ 各 氏の研究があり，いずれ車動的弾性係数が静的弹性係数 よりる大であると報告している。これらの結果よりわ れわれが用いた単緎維の動的弾性係数は Table. III(b) のあのとあまり違わない結果をらるあのと考えてさしつ か贫ないである。

Table. II Effect of resin content on Young's modulus by static and dynamic method in viscose spun rayon yarn and fabric treated with resin.

\begin{tabular}{c|c|cc|l}
\hline \multirow{2}{*}{$\begin{array}{c}\text { Sample } \\
\text { No. }\end{array}$} & $\begin{array}{c}\text { Resin } \\
\text { content }\end{array}$ & \multicolumn{2}{|c}{ Young's modulus dynes $/ \mathrm{cm}^{2}$} \\
\cline { 3 - 4 } & $\%$ & Yarn & \multicolumn{2}{|c}{ Fabric } \\
\hline 100 & 1.7 & $8.29 \times 10^{8}$ & $7.05 \times 10^{7}$ & $8.06 \times 10^{7}$ \\
120 & 4.5 & 10.31 & 7.57 & 7.84 \\
140 & 5.8 & 11.58 & 8.40 & 7.95 \\
160 & 13.5 & 14.29 & 8.90 & 9.61 \\
\hline
\end{tabular}

Table. III. (a) Young's modulus by static stretching on viscose rayon fibres.

\begin{tabular}{c|c|c}
\hline Sample No. & Resin content \% & $\begin{array}{c}\text { Young's modulus. } \\
\text { dynes } / \mathrm{cm}^{2}\end{array}$ \\
\hline 100 & 1.7 & $3.84 \times 10^{10}$ \\
130 & 5.1 & 4.43 \\
160 & 13.5 & 4.15 \\
\hline
\end{tabular}

Table. III(b) Young's modulus by dynamic bending on viscose rayon fibres.

\begin{tabular}{c|c|c|c}
$\begin{array}{c}\text { Sample } \\
\text { No. }\end{array}$ & $\begin{array}{c}\text { Diameter } \\
\mu\end{array}$ & $\begin{array}{c}\text { Young's modulus } \\
\text { dynes } / \mathrm{cm}^{2}\end{array}$ & References \\
\hline $\mathrm{A}$ & 40.6 & $1.08 \times 10^{11}$ & 4 \\
$\mathrm{~B}$ & 253.0 & 1.32 & 5 \\
\hline
\end{tabular}

以上の結果より垟瀻維, 糸招よび織物の動的弾性係数

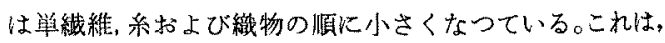
単緎維に対し系なよび織物の棈造上の粗密さが弾性係数 に影響を及ぼするのと考えられる。なおこれらの関倸は 樹脂固着率が增加しても，ほとんど変化を示していない。

また樹脂固着率の增加による単織維，系および織物の 弾性係数の変化については, Fig. 4, Table. II. および Table. III(a) に示すよ 5 K, 動的弾性係数は樹脂固着 率の增加するにしたがつて，增加の傾向を示した。ただ し単緎維の場合は明確とは言えなかつだ。更に樹脂固着 率の增加による静的弾性係数の変化に関しては Table. 
IIK示す上5K，動的弹性係数の場合之同橉，静的弾性 伱数俚樹脂固着率の增加するにしたがつて增加岩示し た。な扣動的弾性係数は静的弾性係数に比较して大部分 のものが大きい倠を示した。

最近哭佑吉, 篠原昭, 松橋房汇の各氏 ${ }^{20)}$ は系の曲将用

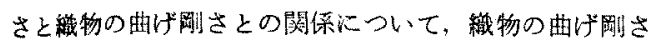

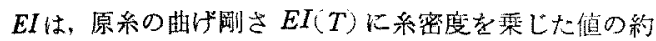
2 倍近く大きいと報皆している。われわれの測定による と，織物の弾性绿数流系の弾性係数の約 1/10 倍である

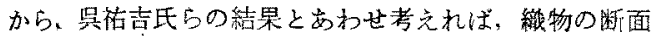
の慣性能繁を糸密度で除した僬は，糸の断面の慣性能率 の約 10〜20 倍になることが解る。このことは織物の崭 面に㧍ける経緯系の交錯状熊を考兑孔ば容易に理解でき ることである。

\section{（3）単織維，糸むよび織物のダンビング・キ ヤバシテーの比較}

絎脂固着率の增加による系括よび織物のダンピンダ． キヤハシシーの变化は Fig. 5 に示すよ 5 に、ダンピン グ・キャ゚シテーは樹脂固着率の增加とは関係なく, 変 らない慎向を示した。しかしながら，糸打よび睵物のダ ンビング・キャパシテーの值を比較すると，各樹脂固着 率ともに，糸の方が小さい値を示した。これは弾性倸数

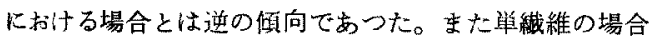

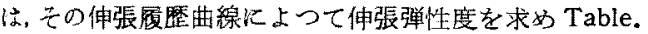
IVに示した。図に示すように,ダンビング・キャパシテー は椡脂固着率の増加によつて明瞭な变化を示さなかつた。

Table. IV Effect of resin content on tensile resilience in viscose rayon fibres treated with resin.

\begin{tabular}{c|c|c}
\hline Sample No. & Resin content \% & Tensile resilience \% \\
\hline 100 & 1.7 & 55.0 \\
130 & 5.1 & 42.9 \\
160 & 13.5 & 71.0 \\
\hline
\end{tabular}

\section{4. 結 諭}

振動リード法を用い，真空中に括いて樹脂加工系捛よ び織物の弹性係数执よびダンピング・キャパシテーを測 定し，次の結果をえた。

（1）樹脂固着率の增加による単絾維，系就よび織物 の弹性係数の变化は，いずれも樹脂固着率が增加 するにしたがつて，弹性係数は增加を示した。る た動的弹性係数の值は，各樹脂固着率において，

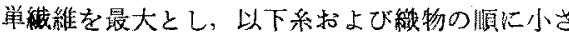
い健を示した。

（2）樹脂固着率の增加による単紻維，采および織物 はダンヒンダ・キャパシテーの変化は，いずれる

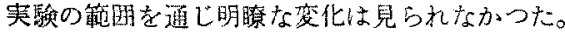
しかしながら，采のダンビング・キャハシテーは 織物のダンビング・キャバシテーよりb小さい倠 を示した。

なお，振動りード法により単絨維における樹脂固着率 之弾性係数执よびダンジング・キャパシテーの関倸に関 する丰駼ができなかつたのは遺答であつたが，これらに

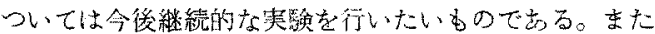
系怙よび織物の弾性绿数执よびダンビング・キャバシテ 一の相互関係比ついてる，現在試料整織中につさ，更に

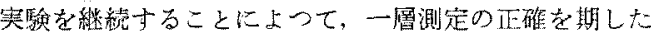
いものである。

最後に実影に，協力された林踦德三郎，佐藤正治の雨 氏に謝意を表するととるに，実駰費の一部を仰いだ山形

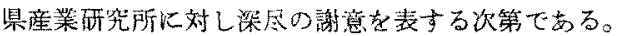

\section{文嗝}

1) J.P. A.Lochner; J. Text. Inst., 40, T 220 (19 49)

2) M.Horio, S. Onogi, C. Nakayama \& K. Yamamoto: J.App.Phys., 22, 966 (1951)

3) B. Lincoln ; J.Text. Inst., 43, T 158 (1952,

4) E. M. Kärholm \& B. Schröder; Text. Res. J., 22, 207 (1953)

5) 小野木重治，安藤昭三；瀻学誌，9，617(1953) $10,32,390$ (1954)

6) J.C. Guthrie, D. H. Morton \& P. H. Oliver ; $J$. Text. Inst., 45, T 912 (1954)

7）吉富達世, 永松一夫, 越山秀一; 九大工学集報, 27, 191 (1955)

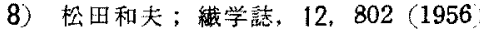

9）小野木重治，宇井久三邲；工化，59，819（1956）

10) M. Horio \& S. Onogi; J.App. Phys., 22, 971 (1951)

11) 小野梗治：高分于，2，506(1953)

12）小野木重治, 安藤昭三, 山本正; 工化，57，251 (1954)

13) A. W. Nolle; J.Polymer. Sci., 5, 1 (1950)

14) 野原繁三，大内筑男；高分子化学， 10，286(19 53)

15）棌井浩，若野精二；工化，59，210（1956)

16) M. Horio \& S. Onogi ; J.App. Phys., 22, 977 (1951)

17) 小野木重治；高分子，3，362(1954）

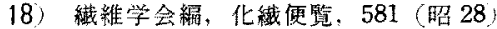

19) W. J.Lyons; Text.Res.J., 19, 123 (1949)

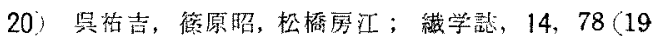
57)

21) F. T.Peirce; J.Text.Inst., 21, T 377 (1930)

22) C.C.Chu, C.L.Cummings \& N. A. Teixeira; Text.Res.J., 20, 539 (1950)

23) R. M. Hoffman \& L.F. Best ; Text. Res.J., 21. $66(1951)$

24) N. J. Abott; Text.Res.J., 21, $435(1951$ 